\title{
Valuasi Ekonomi Limbah Cair Industri Gula dan Spiritus Di Kecamatan Kasihan, Kabupaten Bantul, Propinsi DIY
}

\author{
Farida Afriani Astuti \\ Program Studi Teknik Lingkungan, Fakultas Teknologi Mineral, UPN "Veteran" Yogyakarta \\ Jl. SWK 104 Condongcatur Yogyakarta 55285 \\ Email: faridaafriani.astuti@gmail.com
}

\begin{abstract}
Abstrak
Limbah kegiatan industri dapat menjadi masalah bagi lingkungan jika limbah tersebut dibuang tanpa ada proses pengolahan sebelumnya. Salah satu limbah yang dihasilkan oleh industri gula dan spiritus yang ada di Kecamatan Kasihan adalah limbah cair. Pengaruh limbah cair terhadap kondisi lingkungan dapat dilihat dari kualitas airtanah dan air irigasi di sekitar lokasi industri. Tujuan dari penelitian ini adalah menghitung valuasi ekonomi limbah cair yang dihasilkan oleh industri gula dan spiritus yang ada di Kecamatan Kasihan Kabupaten Bantul.

Metode yang digunakan pada penelitian ini adalah perhitungan valuasi ekonomi limbah cair. Limbah cair dinilai menggunakan Pendekatan Harga Pasar yang Sebenarnya dengan teknik perhitungan berupa Teknik Perubahan Produktivitas dan Teknik Biaya Pengganti. Teknik Perubahan Produktivitas digunakan untuk menghitung nilai limbah cair sebagai peningkat produksi pertanian dan pengurang penggunaan pupuk sedangkan Teknik Biaya Pengganti digunakan untuk menghitung nilai limbah cair sebagai pencemar airtanah. Nilai limbah cair dihitung dalam kurun waktu satu tahun.

Hasil penelitian menunjukkan bahwa nilai limbah cair sebagai pencemar airtanah adalah sebesar Rp 253.608.240 serta nilai limbah cair sebagai peningkat produksi pertanian dan pengurang penggunaan pupuk masing-masing bernilai Rp 37.215.360.000 dan Rp 662.256.000.
\end{abstract}

Kata Kunci : airtanah, limbah cair, pertanian, valuasi ekonomi

\begin{abstract}
The waste from industrial activity could become an issue for the environment if the waste is throw away without preliminary treatment. One of the waste which produced by sugar and spirytus industry in Kasihan Sub-district is waste water. The effect of waste water to the environment could be seen from the quality of groundwater and irrigation water around industrial sites. The purpose of this study is to calculate the economic valuation of wastewater produced by the sugar industry and spirytus in Kasihan Bantul.

The methods that used in this study were Productivity Changes and replacement cost. Productivity changes is used to calculate waste water value as agriculture production increasing and fertilizer utilization decreasing. Replacement cost is used to calculate the value of waste water as groundwater contaminant. The value of waste water calculated within 1 year.
\end{abstract}

The result shows that the economic valuation of waste water as groundwater contaminant is $R p$ 253.608.240; as agriculture production increasing is Rp 37.215.360.000; and as fertilizer utilization decreasing is Rp 662.256.000.

Keywords: agriculture, economic valuation, groundwater, waste water 


\section{PENDAHULUAN}

Perkembangan suatu wilayah dapat dilihat dari adanya peningkatan ekonomi wilayah. Ekonomi wilayah dapat meningkat karena ada beberapa kegiatan ekonomi yang dilakukan oleh masyarakat. Kegiatan ekonomi terdiri dari beberapa sektor, antara lain sektor pertanian, jasa, dan industri. Dari ketiga sektor tersebut, kegiatan ekonomi yang dapat merangsang pertumbuhan kegiatan ekonomi lainnya serta dapat meningkatkan kondisi ekonomi suatu wilayah adalah sektor industri. Hal ini disebabkan karena sektor industri bersifat leading sektor atau sektor pemimpin. Adapun jenis sektor indutri ada beberapa macam, salah satunya adalah industri pengolahan. Industri pengolahan meningkat seiring dengan peningkatan jumlah penduduk disuatu wilayah. Di Kecamatan Kasihan Kabupaten Bantul terdapat industri pengolahan yang sudah sangat terkenal yaitu Industri Gula dan Spiritus PG-PS Madukismo. Keberadaan industri tersebut dapat menimbulkan beberapa pengaruh, baik pengaruh terhadap lingkungan fisik maupun lingkungan sosial-ekonomi masyarakat. Industri tersebut memiliki karakteristik proses produksi (input, proses, dan output) yang berbeda dari industri pengolahan lainnya. Perbedaan karakteristik itulah yang dapat mempengaruhi kualitas lingkungan di sekitarnya terutama dari limbah yang dihasilkan pada setiap tahapan kegiatan produksi yang ada.

Limbah kegiatan industri dapat menjadi masalah bagi lingkungan sekitar jika limbah tersebut dibuang tanpa ada proses pengolahan sebelumnya. Salah satu limbah yang dihasilkan oleh industri gula dan spiritus yang ada di Kecamatan Kasihan adalah limbah cair. Pengaruh limbah cair terhadap kondisi lingkungan dapat dilihat dari kualitas airtanah dan air irigasi di sekitar lokasi industri. Berdasarkan pengaruh yang ditimbulkan akibat limbah cair tersebut, maka selanjutnya dapat dilakukan perhitungan valuasi ekonomi untuk mengetahui nilai ekonomi limbah cair yang berpengaruh terhadap lingkungan. Hal ini didasarkan karena perhitungan valuasi ekonomi berfungsi untuk mengetahui keberpihakan terhadap lingkungan dalam bentuk kuantitatif, (S.Jackson et al, 2014). Tujuan dari penelitian ini adalah menghitung valuasi ekonomi limbah cair yang dihasilkan oleh industri gula dan spiritus yang ada di Kecamatan Kasihan Kabupaten Bantul.

\section{METODE PENELITIAN}

Metode yang digunakan pada penelitian ini adalah perhitungan valuasi ekonomi limbah cair. Perhitungan valuasi ekonomi limbah cair merupakan upaya untuk memberikan nilai kuantitatif terhadap limbah cair yang dihasilkan oleh industri gula dan spiritus baik atas dasar nilai pasar maupun nilai non pasar (Suparmoko, 2012). Dengan kata lain, valuasi ekonomi limbah cair 
merupakan upaya mengestimasikan nilai uang (Rupiah) dari limbah cair yang dihasilkan oleh industri Gula dan Spiritus. Limbah cair dinilai menggunakan Pendekatan Harga Pasar yang Sebenarnya dengan teknik perhitungan berupa Teknik Perubahan Produktivitas dan Teknik Biaya Pengganti,(Pusat Studi Lingkungan Hidup UGM, 2002; Kementerian Negara Lingkungan Hidup, 2007; Suparmoko, 2012).

\subsection{Teknik Perubahan Produktivitas}

\subsubsection{Nilai Ekonomi Limbah Cair sebagai Peningkat Produksi Pertanian}

Formula:

$$
\text { VLc }=(Q 1-Q 2) \times H p \times L s
$$

Keterangan :

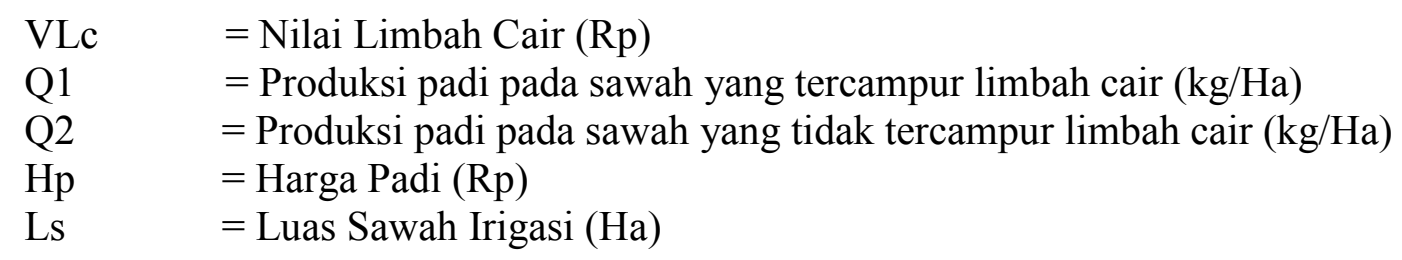

2.1.2. Nilai Ekonomi Limbah Cair sebagai Pengurang Biaya Biaya Input Produksi (Mengurangi Penggunaan Pupuk)

Formula :

$$
\text { VLc }=(N 1-N 2) \times \text { Pp } \times \text { Ls }
$$

Keterangan:

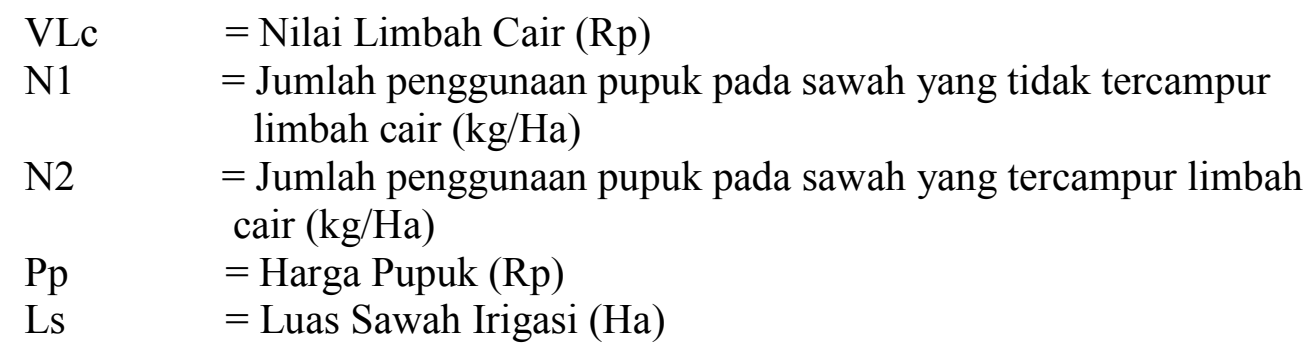

\subsection{Teknik Biaya Pengganti}

2.2.1. Nilai Ekonomi Limbah Cair sebagai Pencemar Airtanah 
Formula:

$$
\text { VLc }=\text { Pa } \times 12 \times n
$$

Keterangan :

$$
\begin{array}{ll}
\text { VLc } & =\text { Nilai Limbah Cair 1th (Rp) } \\
\mathrm{Pa} & =\text { Harga Air Bersih tiap bulan } \\
\mathrm{n} & =\text { Jumlah Pelanggan PAM }
\end{array}
$$

\section{HASIL DAN PEMBAHASAN}

\subsection{Pengaruh Limbah Cair terhadap Kualitas Airtanah dan Air Irigasi}

Limbah cair yang dihasilkan oleh industri gula dan spiritus memiliki dua jenis yang berbeda. Limbah yang pertama adalah limbah cair yang berasal dari proses pembuatan gula, dan yang kedua adalah limbah cair yang dihasilkan oleh proses pembuatan alkohol/spiritus. Keduanya memiliki karakteristik yang berbeda baik karakteristik secara fisik maupun secara kimia. Kedua limbah cair tersebut dibuang melalui saluran irigasi di sekitar lokasi industri dan banyak digunakan oleh para petani untuk mengairi sawah. Keberadaan limbah cair tersebut mempengaruhi kualitas air tanah dan air irigasi di Desa Tirtonirmolo dan Pendowoharjo.

Kualitas airtanah dilihat berdasarkan parameter fisika maupun kimia kemudian dibandingkan dengan baku mutu air kelas I yang ditetapkan oleh Peraturan Gubernur DIY No.20 Tahun 2008. Perbandingan dilakukan untuk mengetahui kualitas airtanah pada setiap sampel apakah masih memenuhi baku mutu air yang telah ditetapkan atau tidak. Sampel airtanah yang diuji sejumlah 11 titik sumur yang tersebar di Desa Tirtonirmolo dan Pendowoharjo. Pengambilan sampel berdasarkan arah aliran airtanah yang ada dikedua desa tersebut. Parameter fisik yang digunakan adalah pH, suhu, TDS (Total Dissolved Solid), TSS (Total Suspended Solid), dan DHL (Daya Hantar Listrik). Parameter kimia yang digunakan adalah minyak lemak, detergent, BOD (Biochemical Oxygen Demand), COD (Chemical Oxygen Demand), dan beberapa ion seperti nitrat, nitrit, sulfida, dan fosfat. Secara keseluruhan, kualitas air tanah yang terdapat pada kesebelas sampel memiliki kondisi yang kurang baik. Kondisi tersebut diperoleh ketika musim giling tiba yaitu pada saat limbah cair mengalir disekitar permukiman warga melalui saluran irigasi yang ada. Ketika musim giling tidak sedang berlangsung kualitas airtanah berbeda-beda antar wilayah. Dari hasil penelitian, terdapat sebagaian airtanah yang kualitasnya cukup bagus ketika tidak musim giling seperti di Dusun Mrisi (S3) padahal ketika musin giling airtanah di dusun tersebut kualitasnya kurang bagus. Selain itu juga terdapat sumur yang tetap memiliki kualitas yang kurang 
bagus meskipun tidak sedang musim giling yaitu di Perumahan Madukismo (S2). Tabel 3.1 merupakan tabel hasil uji kualitas airtanah pada 11 sampel yang diambil di Desa Tirtonirmolo dan Pendowoharjo.

Tabel.1. Hasil Uji Airtanah di Desa Tirtonirmolo dan Pendowoharjo

\begin{tabular}{|c|c|c|c|c|c|c|c|c|c|c|c|c|c|c|}
\hline \multirow[b]{2}{*}{ Parameter } & \multirow[b]{2}{*}{ Satuan } & \multirow{2}{*}{\begin{tabular}{|l|} 
Baku \\
mutu air \\
kelas I
\end{tabular}} & \multicolumn{11}{|c|}{ Hasil Uji Laboratorium Air Tanah } & \multirow[b]{2}{*}{ Metode Uji } \\
\hline & & & $\begin{array}{l}\text { sampel } \\
\text { l }\end{array}$ & \begin{tabular}{|l|} 
sampel \\
2 \\
\end{tabular} & \begin{tabular}{|l|} 
sampd \\
3 \\
\end{tabular} & \begin{tabular}{|l|} 
sampd \\
\end{tabular} & $\begin{array}{l}\text { sampd } \\
\mathbf{5} \\
\end{array}$ & $\begin{array}{l}\text { samped } \\
6\end{array}$ & \begin{tabular}{|l|} 
samped \\
7 \\
\end{tabular} & \begin{tabular}{|l|} 
sampel \\
8 \\
\end{tabular} & \begin{tabular}{|l} 
sampel \\
9 \\
\end{tabular} & \begin{tabular}{|l|} 
samped \\
10
\end{tabular} & \begin{tabular}{|l|} 
samped \\
ll \\
\end{tabular} & \\
\hline Suhu & ${ }^{\circ} \mathrm{C}$ & $\pm 3^{\circ} \mathrm{C}$ & 30,5 & 29,0 & 29,3 & 29,7 & 29,9 & 29,2 & 28,8 & 29,5 & 29,4 & 29,5 & 30,1 & SNI 06-6989.23-2005 \\
\hline $\mathrm{pH}$ & . & $6-8,5$ & 5,6 & 6,5 & 6,9 & 6,9 & 6,8 & 6,9 & 6,4 & 6,8 & 6,8 & 6,8 & 6,6 & SNI 06-6989.11-2004 \\
\hline Detergent & $\mathrm{mgL}$ & 0,2 & $\bar{s}_{0,0001}$ & $\bar{s}_{0,001}$ & $\bar{s}_{0,001}$ & $\bar{s}_{0,001}$ & $\bar{S}_{0,0001}$ & 0,2 & $\bar{s}_{0,001}$ & $\bar{c}_{0,001}$ & 0,0001 & 0,05 & $\overline{0}_{0,001}$ & SNI 06-6989.51-2005 \\
\hline TDS & $\mathrm{mgL}$ & 1000 & 271 & 321 & 281 & 413 & 266 & 303 & 176 & 140 & 207 & 121 & 228 & \begin{tabular}{|l|} 
SNI 06-6989.27-2005 \\
\end{tabular} \\
\hline TSS & $\mathrm{mgL}$ & 0 & 12 & 25 & 11 & 21 & 12 & 13 & 60 & 148 & 12 & 118 & 174 & SNI 06-6989.3-2004 \\
\hline $\begin{array}{l}\text { Minyak } \\
\text { Lemak }\end{array}$ & $\mathrm{mgL}$ & 0,1 & 0 & 0 & 0 & 0 & 0 & 0 & 0 & 0 & 0 & 0 & 0 & SNI 06-6989.10-2004 \\
\hline Nitrat & $\mathrm{mgL}$ & 10 & 0,6 & 0,3 & 3 & 4 & 4 & 1 & 1 & 0,1 & 0,03 & $\frac{\varepsilon}{0,0001}$ & 0,2 & SNI 06-2480-1991 \\
\hline Nitrit & $\mathrm{mgL}$ & 0,06 & 0,01 & 0,01 & 0,02 & 0,01 & 0,01 & 0,01 & 0,003 & 0,004 & 0,004 & 0,01 & 0,03 & SNI 06-6989.9-2004 \\
\hline BOD & $\mathrm{mgL}$ & 2 & 10 & 11 & 5 & 6 & 7 & 6 & 4 & 4 & 3 & 1 & 5 & SNI 06-2503-1991 \\
\hline COD & $\mathrm{mgL}$ & 10 & 20 & 20 & 10 & 20 & 10 & 20 & 10 & 20 & 10 & 20 & 20 & SNI 06-6989.2-2009 \\
\hline Sulfida & $\mathrm{mgL}$ & 0,002 & $\frac{8}{0,002}$ & $\frac{8}{0,002}$ & $\frac{8}{0,002}$ & $\bar{S}_{0,002}$ & $\bar{s}_{0,02}$ & $\frac{5}{0,002}$ & 0,005 & 0,007 & 0,009 & 0,015 & 0,010 & Metode Hach \\
\hline Fosfat & $\mathrm{mgL}$ & 0,2 & 0,01 & 0,5 & 0,2 & 0,01 & 0,05 & 0,6 & 0,001 & 0,3 & 0,05 & 0,1 & 0,5 & SNI 06-6989.31-2005 \\
\hline
\end{tabular}

Sumber: Hasil Uji Lab.Balai PIPBPJK,2011

Tabel 3.1 di atas menunjukkan bahwa dari semua sampel air tanah yang diuji memiliki beberapa parameter yang tidak sesuai dengan baku mutu yang ditetapkan. Sampel airtanah yang memiliki dua parameter yang tidak sesuai dengan baku mutu masih bisa dikatakan kualitasnya cukup baik, akan tetapi sampel airtanah yang memiliki lebih dari dua parameter yang tidak sesuai dengan baku mutu maka dapat dikatakan kualitasnya kurang baik. Hasil pengujian kualitas airtanah pada tabel 3.1 menunjukkan bahwa hanya terdapat dua sampel airtanah yang memiliki kualitas yang cukup baik, yaitu sampel 3 (S3) dan sampel 5 (S5), sedangkan untuk kesembilan sampel lainnya (S1, S2, S4, S6, S7, S8, S9) memiliki kualitas yang kurang baik. Dengan demikian, baik buruknya kualitas airtanah bukan hanya dipengaruhi oleh jarak dengan lokasi industri akan tetapi juga dipengaruhi oleh arah aliran airtanah dan jarak dengan saluran pembuangan limbah cair.

Pengaruh keberadaan industri gula dan spiritus yang kedua dilihat dari kualitas air irigasi. Pengaruh terhadap air irigasi terjadi ketika musim giling tiba. Ketika musim giling belum tiba, maka air 
irigasi tidak tercampur oleh limbah dari proses produksi melainkan hanya tercampur limbah cair dari pencucuian mesin-mesin penggilingan. Dengan demikian, pengaruh limbah cair terhadap air irigasi dirasakan ketika bukan musim giling dan musim giling, hanya saja pengaruh keduanya berbeda.

Secara fisik, air irigasi yang tercampur limbah cair memiliki warna yang lebih keruh dan berwarna kecoklatan dan memiliki bau yang sedikit menyengat. Tabel 2 merupakan hasil uji laboratorium terhadap kualiatas air irigasi yang tercampur oleh limbah cair.

Tabel .2. Hasil Uji Sampel Air Irigasi Tercampur Limbah Cair

\begin{tabular}{|c|c|c|c|c|c|}
\hline \multirow[b]{2}{*}{ Parameter } & \multirow[b]{2}{*}{ Satuan } & \multirow{2}{*}{$\begin{array}{l}\text { Baku Mutu Air } \\
\text { Kelas } 4\end{array}$} & \multicolumn{2}{|c|}{ Hasil Uji Air Irigasi } & \multirow[b]{2}{*}{ Metode Uji } \\
\hline & & & $\begin{array}{l}\text { Sampel } \\
\text { 1A }\end{array}$ & $\begin{array}{l}\text { Sampel } \\
2 \mathrm{~A}\end{array}$ & \\
\hline Suhu & $\mathrm{C}$ & 3 & 31,7 & 30,9 & SNI 06-6989.23-2005 \\
\hline $\mathrm{pH}$ & & $5-9,0$ & 6,6 & 6,5 & SNI 06-6989.11-2004 \\
\hline DHL & $\mu \mathrm{mhos} / \mathrm{cm}$ & & 291 & 366 & SNI 06-6989.1-2005 \\
\hline TDS & $\mathrm{mg} / \mathrm{L}$ & 2000 & 131 & 165 & SNI 06-6989.27-2005 \\
\hline TSS & $\mathrm{mg} / \mathrm{L}$ & 400 & 52 & 18 & SNI 06-6989.3-2004 \\
\hline Nitrat & $\mathrm{mg} / \mathrm{L}$ & 20 & 1 & 3 & SNI 06-2480-1991 \\
\hline BOD & $\mathrm{mg} / \mathrm{L}$ & 12 & 73 & 285 & SNI 06-2503-1991 \\
\hline COD & $\mathrm{mg} / \mathrm{L}$ & 100 & 104 & 692 & SNI 06-6989.2-2009 \\
\hline Sulfida & $\mathrm{mg} / \mathrm{L}$ & 0 & 0,044 & 0,130 & Metode Hach \\
\hline Fosfat & $\mathrm{mg} / \mathrm{L}$ & 5 & 0,1 & 0,2 & SNI 06-6989.31-2005 \\
\hline
\end{tabular}

Sumber: Hasil uji Lab.Balai PIPBPJK, 2011

Hasil uji tabel.2. menunjukkan terdapat dua sampel air irigasi yang diteliti. Sampel pertama (1A) merupakan sampel air irigasi yang belum masuk kedalam petak sawah pertanian dan belum terpengaruh proses pengelolaan pertanian atau disebut sampel air irigasi inlet. Sampel kedua (2A) merupakan sampel air irigasi yang sudah masuk kedalam petak sawah pertanian dan sudah mendapatkan pengaruh dari pengelolaan pertanian yang ada atau disebut sampel air irigasi outlet . Pengambilan sampel irigasi inlet dan outlet bertujuan untuk mengetahui perubahan kualitas air irigasi yang belum terpengaruh oleh pengolahan pertanian dengan yang sudah mendapatkan pengaruh dari pengolahan pertanian. Keduanya digunakan untuk membuktikan kebenaran jika limbah cair dapat menambah unsur hara yang dibutuhkan tanaman seperti nitrat dan phospat yang sering diberitakan. 
Tabel . 2 juga menunjukkan bahwa untuk sampel 1A terdapat 3 parameter yang melebihi baku mutu air kelas 4 yang telah ditetapkan sebagai baku mutu air yang cocok untuk pertanian. Ketiga parameter yang melebihi tersebut adalah BOD, COD, dan sulfida. Kondisi yang sama juga diperlihatkan oleh hasil uji sampel 2A, yang memiliki 3 parameter yang melebihi baku mutu air kelas 4 yang telah ditetapkan, yaitu BOD, COD, dan sulfida.

Hasil uji sampel 1A dengan sampel 2A memang memperlihatkan perbedaan di setiap hasil per parameternya. Sampel 2A memiliki nilai yang lebih tinggi dibandingkan pada sampel 1A disetiap parameter, terutama untuk parameter DHL, TDS, Nitrat, BOD, COD, Sulfida, Fosfat. Berikut merupakan diagram yang menunjukkan perubahan nilai pada parameter yang memiliki perbedaan yang sangat mencolok pada irigasi inlet dan outlet.

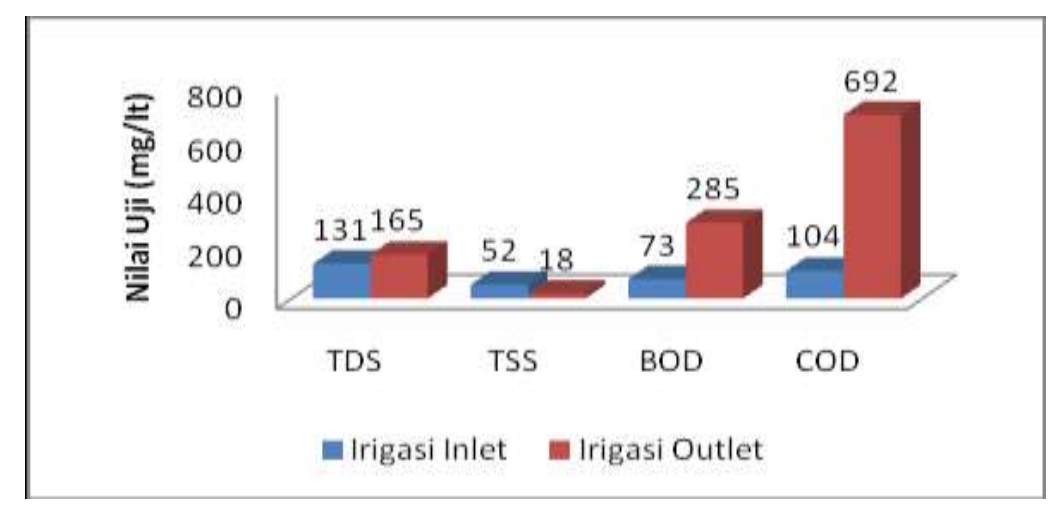

Gambar 3.1 Diagram Perubahan nilai irigasi inlet dan outlet

Peningkatan disetiap parameter tersebut menunjukkan bahwa dengan adanya pengelolaan pertanian semakin menambah kandungan unsur hara seperti kandungan nitrat, sufida, dan fosfat yang berpengaruh terhadap kesuburan tanaman. Selain itu juga mempertinggi unsur-unsur yang terkandung didalam air yang digunakan untuk irigasi seperti BOD, COD, DHL, dan TDS. Dengan demikian dapat dikatakan bahwa irigasi tercampur limbah cair dapat menambah kandungan unsur hara tanah.

Kualitas air irigasi yang tidak tercampur oleh limbah cair terdapat di sebelah utara industri gula dan spiritus. Semua lahan pertanian yang berada diutara industri tersebut menggunakan air irigasi yang berasal dari Sungai Dongkelan Kauman atau Sungai Winongo. Sampel air irigasi yang tidak tercampur limbah cair diambil di Dusun Plurugan dan Jeblok, Desa tirtonirmolo. Secara fisik air 
irigasi ini berwarna lebih cerah dan tidak berbau. Sebagai pembanding dengan kualitas air irigasi yang tercampur limbah cair, berikut disajikan hasil uji kualitas air irigasi yang tidak tercampur limbah cair pada tabel .3.

Tabel .3. Hasil Uji Sampel Air Irigasi Tidak Tercampur Limbah Cair

\begin{tabular}{|l|l|l|l|l|l|}
\hline \multirow{2}{*}{ Parameter } & \multirow{2}{*}{ Satuan } & \multirow{2}{*}{$\begin{array}{l}\text { Baku Mutu } \\
\text { Air Kelas 4 }\end{array}$} & \multicolumn{2}{|l|}{ Hasil Uji Air Irigasi } & \multirow{2}{*}{ Metode Uji } \\
\cline { 5 - 6 } & & & Sampel 1B & Sampel 2B & \\
\hline Suhu & $\mathrm{C}$ & 3 & 30,1 & 30,1 & SNI 06-6989.23-2005 \\
\hline pH & & $5-9,0$ & 6,9 & 6,9 & SNI 06-6989.11-2004 \\
\hline DHL & umhos/cm & & 243 & 247 & SNI 06-6989.1-2005 \\
\hline TDS & $\mathrm{mg} / \mathrm{L}$ & 2000 & 110 & 111 & SNI 06-6989.27-2005 \\
\hline TSS & $\mathrm{mg} / \mathrm{L}$ & 400 & 60 & 20 & SNI 06-6989.3-2004 \\
\hline Nitrat & $\mathrm{mg} / \mathrm{L}$ & 20 & 0,1 & 0,3 & SNI 06-2480-1991 \\
\hline BOD & $\mathrm{mg} / \mathrm{L}$ & 12 & 10 & 4 & SNI 06-2503-1991 \\
\hline COD & $\mathrm{mg} / \mathrm{L}$ & 100 & 59 & 20 & SNI 06-6989.2-2009 \\
\hline Sulfida & $\mathrm{mg} / \mathrm{L}$ & 0 & 0,012 & 0,013 & Metode Hach \\
\hline Fosfat & $\mathrm{mg} / \mathrm{L}$ & 5 & 0,1 & 0,1 & SNI 06-6989.31-2005 \\
\hline
\end{tabular}

Sumber: Hasil uji Lab.Balai PIPBPJK, 2011

Tabel .3. di atas menunjukkan bahwa tidak ada parameter yang melebihi baku mutu air kelas 4 kecuali parameter sulfida. Hal itu menunjukkan bahwa air irigasi sudah sesuai untuk tanaman pertanian.

\subsection{Valuasi Ekonomi Limbah Cair}

\subsubsection{Nilai Ekonomi Limbah Cair sebagai Pencemar Airtanah}

Dari penjelasan sebelumnya terlihat bahwa limbah cair memiliki pengaruh terhadap airtanah dan air irigasi. Dari kedua pengaruh tersebut maka selanjutnya dilakukan perhitungan valuasi ekonomi terhadap limbah cair. Hal ini bertujuan untuk melihat estimasi nilai rupiah yang ditimbulkan oleh limbah cair. Dengan hasil perhitungan ini maka dapat diketahui besaran pengaruh positif dan negatif dari limbah cair bagi lingkungan dalam satuan rupiah.

Pengaruh limbah cair yang pertama adalah terhadap kualitas airtanah. Dari hasil uji kualitas airtanah menunjukkan bahwa limbah cair mencemari airtanah sehingga masyarakat harus mencari sumber air bersih sebagai pengganti. Nilai ekonomi limbah cair sebagai pencemar airtanah dapat dihitung melalui biaya yang dikeluarkan untuk memperoleh air bersih. Hasil penelitian menunjukkan bahwa 
masyarakat yang air sumurnya tercemar memilih menggunakan PAM sebagai sumber air bersih atau meminta dari sumur tetangga yang kualitas airnya lebih baik. Jumlah total pelanggan PAM di Desa Tirtonirmolo dan Pendowoharjo sebanyak 470 pelanggan.

Pengeluaran pada setiap bulan untuk membayar tagihan air PAM di kedua desa tersebut dapat digunakan untuk menghitung nilai valuasi ekonomi limbah cair sebagai pencemar air tanah dengan Teknik Biaya Pengganti. Berdasarkan data penggunaan air PAM diperoleh rata-rata biaya untuk mendapatkan air bersih sebesar Rp 44.966/bulan. Sehingga nilai limbah cair sebagai pencemar air tanah adalah di Desa Tirtonirmolo dan Desa Pendowoharjo akibat keberadaan limbah cair dalam 1 tahun adalah sebesar Rp 253.608.240.

\subsubsection{Nilai Ekonomi Limbah Cair sebagai Peningkat Produksi Pertanian}

Nilai ekonomi limbah cair sebagai peningkat produksi pertanian merupakan nilai dari limbah cair yang memberikan pengaruh positif terhadap kondisi pertanian disekitarnya. Hasil penelitian menunjukkan bahwa hasil produksi pertanian sawah yang menggunakan air irigasi tercampur oleh limbah cair memiliki hasil yang lebih tinggi dibandingkan dengan hasil produksi pertanian pada sawah yang menggunakan air irigasi tidak tercampur oleh limbah cair. Kondisi tersebut dipengaruhi oleh kandungan unsur hara yang ada dalam limbah cair yang dapat meningkatkan kesuburan tanaman sehingga hasil panen ikut meningkat. Gambar .2. menunjukkan peningkatan rata-rata produksi padi pada sawah yang menggunakan air irigasi tercampur limbah cair.

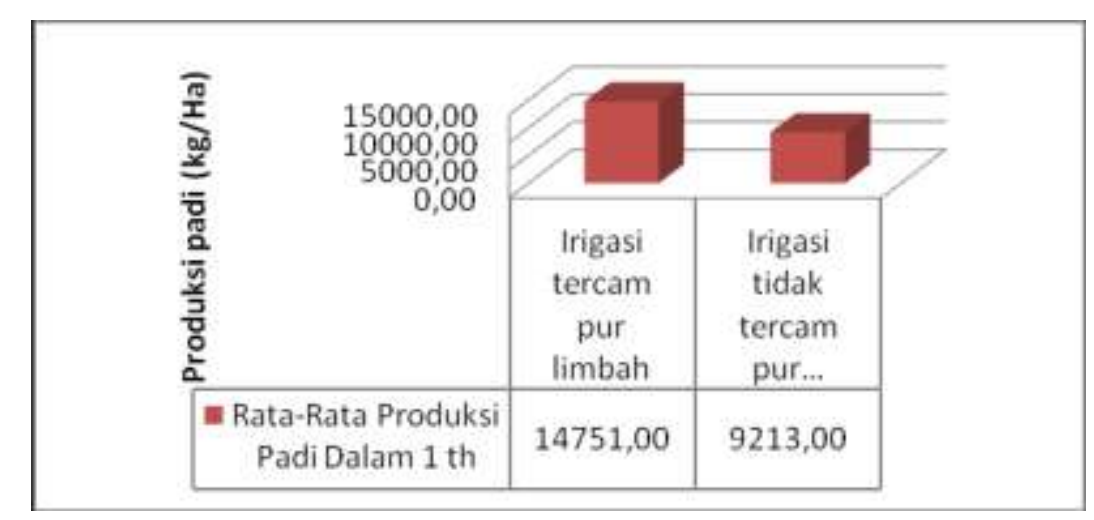

Gambar .2 Diagram Rata-Rata Produksi Padi 
Nilai valuasi ekonomi limbah cair berdasarkan Teknik Perubahan Produktifitas dalam 1 tahun sebagai peningkat produksi pertanian adalah $\mathrm{Rp} 37.215 .360$ dengan nilai $\mathrm{Q} 1=14.751 \mathrm{~kg} / \mathrm{Ha}, \mathrm{Q} 2=$ $9.213 \mathrm{~kg} / \mathrm{Ha}, \mathrm{Hp}=\mathrm{Rp} 6000 \mathrm{dan} \mathrm{Ls}=1.120 \mathrm{Ha}$.

3.2.3. Nilai Ekonomi Limbah Cair sebagai Pengurang Biaya Input Produksi (Mengurangi Penggunaan Pupuk)

Nilai ekonomi limbah cair sebagai pengurang penggunaan pupuk merupakan nilai dari limbah cair yang juga memberikan pengaruh positif terhadap kondisi pertanian disekitarnya. Berdasarkan hasil penelitian, jumlah penggunaan pupuk pada sawah yang menggunakan air irigasi tercampur limbah cair lebih sedikit dibandingkan dengan penggunaan pupuk pada sawah yang tidak tercampur oleh limbah cair. Gambar .3 menunjukkan perbandingan penggunaan pupuk pada sawah yang tercampur limbah cair dengan yang tidak tercampur.

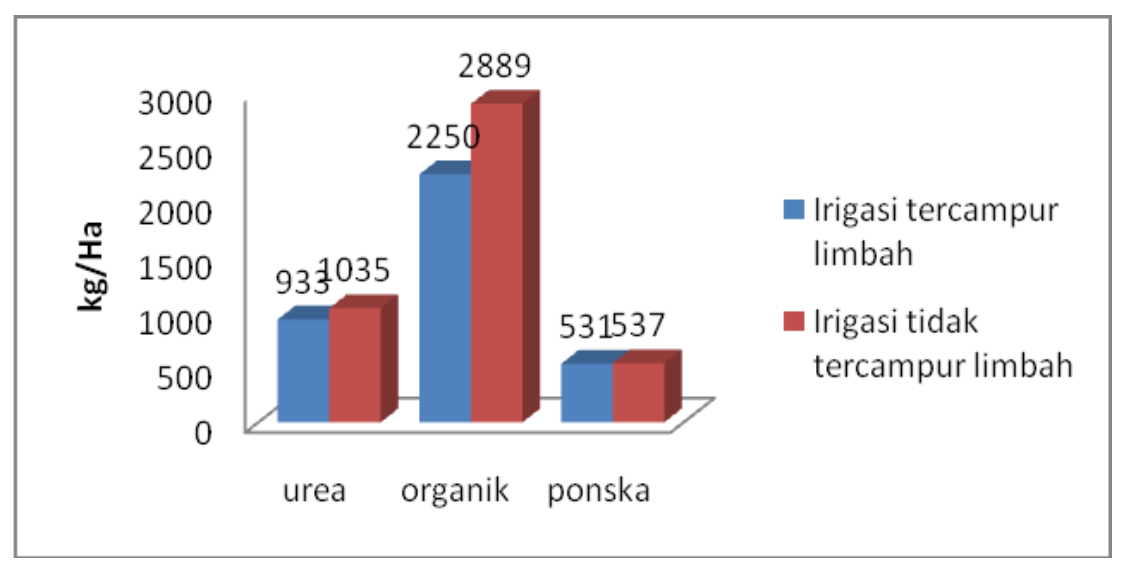

Gambar . 3. Diagram Rata-Rata Penggunaan Pupuk

Adapun perhitungan valuasi ekonomi limbah cair sebagai pengurang penggunaan pupuk dalam 1 tahun dapat dilihat tabel . 4. dibawah ini: 
Tabel . 4. Nilai Limbah Cair sebagai Pengurang Penggunaan Pupuk

\begin{tabular}{|l|l|l|l|l|l|}
\hline \multirow{2}{*}{ Jenis Pupuk } & \multicolumn{4}{|c|}{ Nilai } & \multirow{2}{*}{ VLc (Rp) } \\
\cline { 2 - 5 } & N1 (Kg/Ha) & N2 (Kg/Ha) & Pp (Rp/Kg) & Ls (Ha) & \\
\hline Urea & 1.035 & 933 & 2.500 & 1.120 & 285.600 .000 \\
\hline Organik & 2.889 & 2.250 & 500 & 1.120 & 357.840 .000 \\
\hline Ponska & 537 & 531 & 2.800 & 1.120 & 18.816 .000 \\
\hline \multicolumn{5}{|c|}{ Total } & 662.256 .000 \\
\hline
\end{tabular}

\section{KESIMPULAN}

Keberadaan limbah cair industri gula dan spiritus mempengaruhi kualitas airtanah dan air irigasi yang ada disekitarnya. Pengaruh keduanya dapat dihitung secara ekonomi menggunakan Teknik Biaya Pengganti dan Teknik Perubahan Produktivitas dalam periode satu tahun. Teknik Biaya Pengganti digunakan untuk menghitung nilai limbah cair sebagai pencemar airtanah dan diperoleh hasil sebesar Rp 253.608.240. Sedangkan Teknik Perubahan Produktivitas digunakan untuk menghitung nilai limbah cair sebagai peningkat produksi pertanian dan pengurang penggunaan pupuk yang masing-masing bernilai Rp 37.215.360.000 dan Rp 662.256.000.

\section{DAFTAR PUSTAKA}

Badan Pengendalian Dampak Lingkungan Daerah DIY. 2008. Peraturan Gubernur Daerah Istimewa Yogyakarta Nomor 20 Tahun 2008 Tentang Baku Mutu Air Di Provinsi Daerah Istimewa Yogyakarta. Yogyakarta.

Sue Jackson, Finn Marcus, and Scheepers Kelly. 2014. The Use of Replacement Cost Method to Assess and Manage The Impacts of Water Resource Development on Australian Indigenous Customary Economies. Journal of Environmental Management. Volume 135. Halaman 100109.

Kementrian Negara Lingkungan Hidup. 2007. Panduan Valuasi Ekonomi Sumberdaya Alam dan Lingkungan. Jakarta

Pusat Studi Lingkungan Hidup UGM. 2002. Paket Pelatihan Ekonomi Lingkungan. Yogyakarta. Suparmoko, M dan Ratnaningsih Maria. 2012. Ekonomika Lingkungan. BPFE Yogyakarta. 